\title{
Helicopter Turboshaft Engine Emission Estimation Based on Standard Flight Profile
}

\author{
József TÓTH ${ }^{1}$, László KAVAS ${ }^{2}$, Benjámin RÓZSA ${ }^{3}$ \\ ${ }^{1}$ National University of Public Service Ludovika, Department of Aircraft and Engines H- 5008 Szolnok, Hungary \\ ${ }^{2}$ National University of Public Service Ludovika, Department of Aircraft and Engines H- 5008 Szolnok, Hungary \\ ${ }^{3}$ National University of Public Service Ludovika, Department of Aircraft and Engines H- 5008 Szolnok, Hungary
}

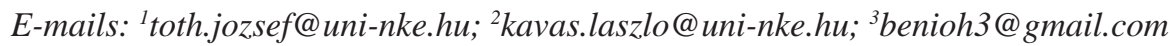

\begin{abstract}
Over the past decades, environmental protection, including regulation of air pollution, has become an important economic and political issue. Although aviation accounts for only $2 \%$ of atmospheric pollution, regulation at national, international and global level is still very important.

The high-level aim of our current research is to determine the emissions of aircraft engines in the defense sector and to explore ways to reduce them by using alternative fuels, focusing military aviation. This article presents the methodology for developing a standard flight profile, which is the basis for calculating the operational emissions of military helicopters.
\end{abstract}

KEY WORDS: turboshaft engine, emission, alternative jet fuel, air pollution, helicopter operation

\section{Introduction}

Reducing emissions of greenhouse gases $(\mathrm{GHG})$ from the transport sector is an important challenge in the fight against climate change. The International Civil Aviation Organization (ICAO), the committees of the European Union, have developed various strategies based on long-term forecasts. As a result, the CORSIA system was created and currently approved until 2035. The CORSIA system includes measures on aircraft technology, engine development, air traffic management, and sustainable alternative fuels. However, this system only contains requirements for commercial aviation to, so for the public aviation, and especially the defense sector have limited application [1].

For turbofan-powered aircraft, ICAO standards are available to estimate emissions for the operational flight profile. Although helicopters are a smaller source of air traffic emissions, but its play a very important role in non-commercial aviation. The helicopter emissions is extremely difficult to assess because of the emission data of turboshaft engines are generally not open to the public, and the operation flights is much more complex, so there is currently no generally accepted methodology to calculate absolute emissions of helicopters [2].

Federal Office of Civil Aviation (FOCA) in Switzerland has published a methodological guide on helicopter engine emissions and an associated database [5,10]. It provides detailed guidance for estimating helicopter emissions under operational conditions, although it pays less attention to the complexity of flight tasks and corresponding flight profiles. In addition, the estimated accuracy of the calculations is around $15 \%$, which is quite high in engineering and terms. The FAA Aviation Environmental Design Tool (AEDT), the latest version of which also allows the calculation of the distribution and inventory of emissions, provides a more accurate calculation. This software system models aircraft performance in space and time to estimate noise, fuel consumption and emissions [7]. A detailed calculation procedure for calculating aircraft performance can be found in S. Newman's (1994) book. In the main body of the book, methods have been described which enable the calculation of the power necessary to allow a helicopter to operate at a given weight and at a given speed. The results of these calculations, when combined with appropriate engine data, enable the fuel consumption to be determined [8]. An integrated multidisciplinary simulation framework is presented by Ali I. Goulos and V. Pachidis (2015), which is used for the comprehensive evaluation of helicopter engine complex systems at the mission level. The proposed methodology includes a wide range of unique modeling theories applicable to helicopter flight dynamics, gas turbine engine performance, and a new physics-based mixed reactor model for rapid estimation of various types of helicopter emissions [9]. When applying the method and approach, it is possible to use modern simulation procedures, which further increases the accuracy of the obtained results and a better approximation to reality.

\footnotetext{
${ }^{1}$ Corresponding author.

E-mail address: toth.jozsef@uni-nke.hu
} 
Taking the above into account, we have developed the methods and process that best suit the research goal and also fit the research infrastructure, as shown in Figure 1. The first step in the process is to create a standard flight cycle (LTO = Landing and take off) that best represents the profile appropriate to the tasks of the particular helicopter type. If the particular type of helicopter is equipped with a flight data recorder system, the standard LTO cycle can be generated by statistical evaluation of the data from the archived registries. Knowing the standard flight profile, the required engine power for each flight mode can be determined. Using the thermodynamic model of the engine, the amount of fuel consumption can be calculated. If a thermodynamic model is not available, the throttle and altitude characteristics can be used to estimate fuel consumption.

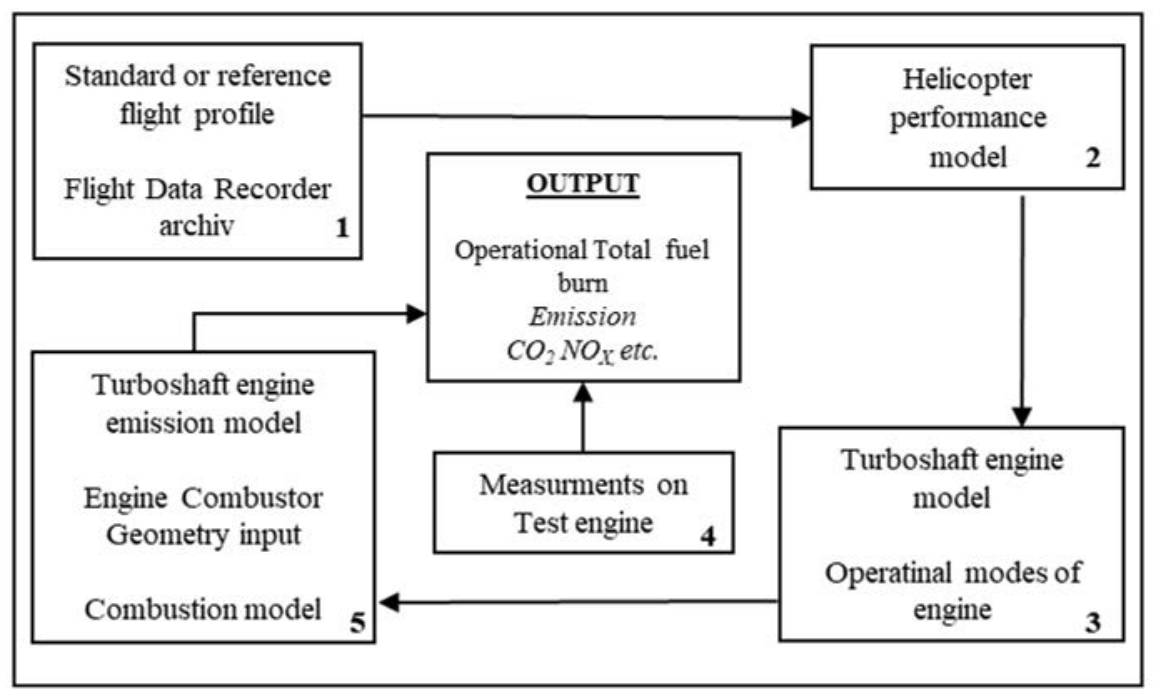

Fig.1. Multidisciplinary framework and process on estimation of turboshaft engine emission.

The most complex task is to model the combustion process in the combustion chamber of the engine, as combustion takes place here in a complex spatial flow space, which can usually be described by a large number of chemical reaction kinetic equations.

Experiments with the test engine play an important role in the process, as we can refine and validate the models used by using the emission values measured by standard experiments.

\section{Methodological Background}

In order to assess emission of turboshaft engine, it is advisable to define a standard flight profile LTO cycle that can be used to estimate individual helicopter emissions for each type of alternative fuel. The standard flight profile is modelled on that used by ICAO. However, it should be taken into account that helicopters use several different procedures, so the operating mode of the engines must be determined accordingly. It should also be taken into account during the remainder of the cycle that helicopters perform their special flight duties over a wide altitude and speed range. With this in mind, the standard LTO cycle should be defined for further calculations. Creating a standard flight profile is an extremely difficult task because, depending on the flight task, the helicopter flies over a very wide range of speeds and altitudes. This is especially true for military tasks (with the exception of simple air transport) or for the training of pilots. Due to the intensive manoeuvres used in flight for these tasks, the fluctuations in speed and altitude are so great that the possibility of standardization is ruled out. One solution to the former problem is to design the flight profile based on the mode of operation of the engine. A specific engine mode and power range can be assigned to each flight phase (suspension, ascent, horizontal flight in cruising mode, etc.), which can be determined by processing the FDR archive data. In the AEDT database for each helicopter, there are six helicopter operational mode adjustments: vertical ascent, vertical descent, depart with horizontal acceleration, approach with horizontal deceleration, depart with climbing acceleration, and approach with descending deceleration. 


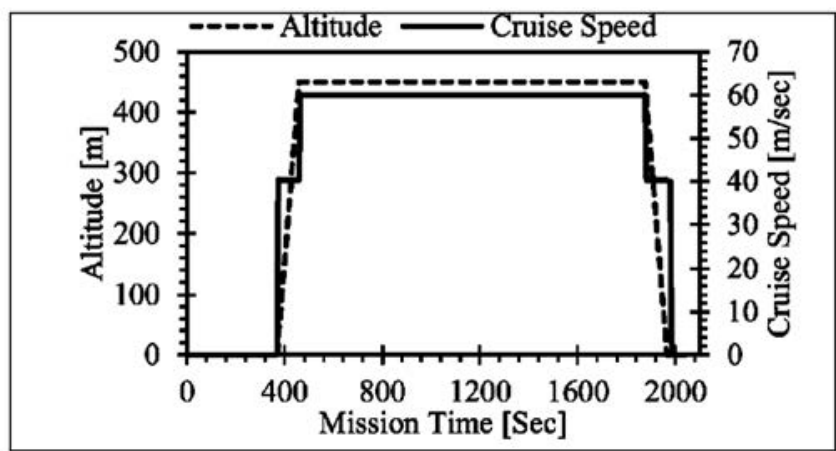

Fig.2. Example mission profile.

Another solution could be to create so-called reference profiles, which can be developed in connection with different flight tasks. Another solution could be to create so-called reference profiles, which can be developed in connection with different flight tasks.

Examples include lifting weights, skydiving, or possibly practicing emergency procedures. To maintain simplicity and consistency each reference mission was simply designed to fly a straight line trajectory and comprised the following flight segments; (1) Idle Before Take-off, (2) Hover, (3) Climb, (4) Cruise, (5) Descent, (6) Idle After Land. An example mission profile is presented in Fig. 2.

The most important methodological elements of the research task are the preparation and adaptation of the mathematical model of the engines, the application of simulation to the processes of the combustion chamber and the pursuance of experiments with the test engine $[3,4]$. The required engine data were determined from the aircraft operating documentation [6].

Based on the engine mode for the flight profile, engine emissions were determined using the method developed by FOCA [5].

\section{Investigations and Results}

Preliminary calculations were performed on the TV2-117 engine on the Mi- 8 helicopter. This type of helicopter has been in the system of Hungaryan Air Forces for almost 50 years, so it has enough data and experience to perform the necessary calculations.

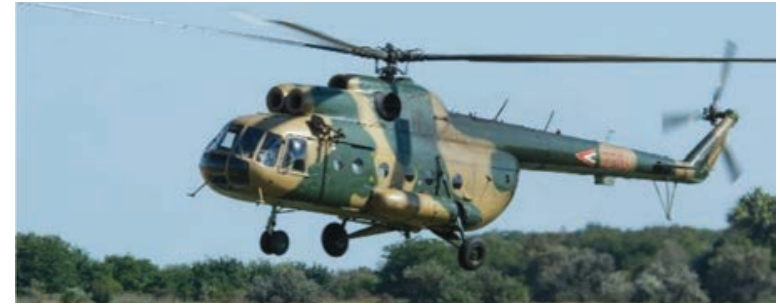

Fig. 3. Helicopter Mi-8.

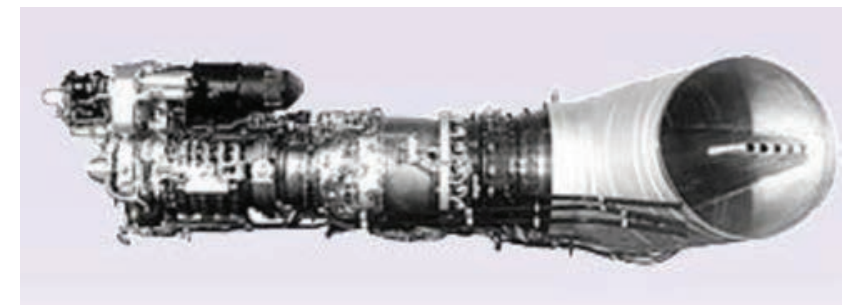

Fig. 4. Helicopter engine TV2-117A.

To determine the standard flight profile, we collected archived flight records of a helicopter of a given page number from January 2019 to the present day. Statistical processing of the entire data set is still ongoing, but we have taken some typical flight data from the resulting data set to perform preliminary calculations.

The first difficulty in developing a standard flight profile is to choose the way the helicopter takes off mode, as this is significantly different from the procedures for a fixed wing aircraft. Take off is the accelerated movement of the helicopter from the launch site to a safe speed gain and height over obstacles. Depending on the method of acceleration, the Mi-8 uses 3 types of takeoff:

1. helicopter takeoff using the influence of "ground effect", in which, after hovering, acceleration or part (beginning) of acceleration is performed in the zone of the "ground effect" at an altitude of at least $1.5+$ $2.0 \mathrm{~m}$ from the ground to the chassis wheels;

2. helicopter take-off out of "ground effect", i.e. vertical climb, exceeding the height of obstacles by at least $10 \mathrm{~m}$, and acceleration to the required forward speed outside the zone of influence of the "ground effect";

3. takeoff with a short takeoff run, i.e. acceleration of the helicopter along the runway to a speed not 
exceeding $30-40 \mathrm{~km} / \mathrm{h}$, separation of the helicopter from the ground and further acceleration with simultaneous climb.

The take-off method is chosen depending on the following factors:

- $\quad$ the size and condition of the take-off area;

- $\quad$ elevation of the site above sea level;

- $\quad$ air approaches to the site;

- takeoff weight of the helicopter;

- $\quad$ outside air temperature;

- $\quad$ wind speed and direction.

Preliminary analysis of the FDR data obtained showed that procedure No.3 was used on a significant number of flights. However, the highest fuel consumption may occur for take-off mode No.2. mode):

Each phase of flight has defined prescribed engine modes, for the TV2 engine these are (exept Low gas

- Take-off (maximum) mode - a mode in which the engine develops maximum power during continuous operation for a time limited by the conditions of the strength of parts (no more than 6 minutes). The takeoff mode is used when taking off and landing a helicopter.

- The nominal operating mode - this mode is mainly used for climbing. In addition, the specific fuel consumption in this mode is less than in cruising. Therefore, the nominal mode can be used to obtain the minimum kilometer fuel consumption when flying a helicopter at a range, route flight. In nominal mode, an operating time of not more than $40 \%$ of the total resource is allowed.

- Cruising mode - the mode is used during a long flight to obtain a minimum hourly fuel consumption. In crusing mode, an operating time is unlimited.

- Each phase of the flight has defined, prescribed engine modes, so that the total fuel consumption can be calculated compared to the flight profile. Using the methods mentioned earlier, the end result is emission values specific to the helicopter type. A preliminary results obtained by processing some flight data are shown in Table 1.

Table 1.

The engine emission values in different operating modes

\begin{tabular}{|c|c|c|c|c|c|c|}
\hline $\begin{array}{c}\text { Operation } \\
\text { mode of } \\
\text { engine }\end{array}$ & $\begin{array}{c}\text { Mean } \\
\text { operating \% } \\
\text { power per } \\
\text { engine }\end{array}$ & $\begin{array}{c}\text { One hour } \\
\text { fuel (kg) }\end{array}$ & $\begin{array}{c}\text { One hour } \\
\text { NOx (kg) }\end{array}$ & $\begin{array}{c}\text { One hour HC } \\
\mathbf{( k g )}\end{array}$ & $\begin{array}{c}\text { One hour CO } \\
\text { (kg) }\end{array}$ & $\begin{array}{c}\text { One hour } \\
\text { PM non vol. } \\
\text { (kg) }\end{array}$ \\
\hline 1 & 67 & 311 & 5.428 & 1.108 & 1.336 & 0.150 \\
\hline 2 & 80 & 348 & 6.716 & 1.024 & 1.228 & 0.182 \\
\hline 3 & 100 & 405 & 8.956 & 0.945 & 1.126 & 0.235 \\
\hline
\end{tabular}

\section{Conclusions}

Using the procedure mentioned here can be an important point of reference for future decision-making on the use of different alternative fuels. At the same time, the economic dimension of the problem, which takes into account the entire life cycle of fuels, needs to be analysed and is a key issue for environmental safety research.

\section{Acknowledgements}

This work was supported by the European Regional Development Fund (GINOP 2.3.2-15-2016-00007, "Increasing and integrating the interdisciplinary scientific potential relating to aviation safety into the international research network at the National University of Public Service - VOLARE"). The project was realised through the assistance of the European Union, and co-financed by the European Regional Development Fund.

\section{References}

1. M.D. Staples et al. Aviation $\mathrm{CO} 2$ emissions reductions from the use of alternative jet fuels https://doi. org/10.1016/j.enpol.2017.12.007. Energy Policy 114 (2018) 342-354

2. Varga B. Helikopter gázturbinás hajtóművek hatásfok növelésének problémái. (2011) Repüléstudományi 
Közlemények (1997-től) 1417-0604 1789-770X 2011/2 p.15-24.

3. Óvári Gy, Kavas L, Varga B. The turbine inlet temperature and compressor pressure ratio the siamese twins of the gas turbine engines. (2016) Scientific Research and Education in the Air Force - AFASES 2016 2247-3173 2016 (1) p. 393-398.

4. Óvári Gy, Varga B, Rozovicsné Fehér K, Tóth J. Specific Net Work and Efficiency Analyses of Gas Turbine Engines Using Thermal Mathematical Model In: Rolandas, Makaras; Robertas, Keršys; Povilas, Gražulis; Rasa, Džiaugienė (szerk.) Proceedings of 19th International Scientific Conference Transport Means 2015. Kaunas, Litvánia : Technologija, (2015) p. 67-70.

5. FOCA, CH-3003 Guidance on the Determination of Helicopter Emissions. Edition 2, Dec 2015, Available from: https://www.bazl.admin.ch/bazl/en/home/specialists/regulations-and-guidelines/environment/pollutantemissions/triebwerkemissionen/guidance-on-the-determination-of-helicopter-emissions.html [online citaton: 05-12-2019]

6. Авиационный турбовальный двигатель ТВ2-117А и редуктор ВР-8А. Руководство по технической эксплуатации. Москва « Машиностроение » 1987.

7. Aviation Environmental Design Tool (AEDT) Version 3b. Technical Manual. September 2019. Available from: https://aedt.faa.gov/Documents/AEDT3b_TechManual.pdf [online citation: 12-08-2020]

8. S. Newman Performance and Mission Calculation The Foundations of Helicopter Flight,.Elsevier, 1994. ISBN: 9780340587027

9. F. Ali, I. Goulos, V. Pachidis An integrated methodology to assess the operational and environmental performance of a conceptual regenerative helicopter. Aeronautical Journal -New Series- January 2015 DOI: 10.1017/ S0001924000010253

10. J. Tóth, G. Óvári, I. Pogácsás Estimation of Helicopter Turboshaft Engines’ Emission Using Flight Data Recorder Archives In: V, Ostaševičius (szerk.) Transport means 2019: Sustainability: Research and Solutions : PROCEEDINGS OF THE 23rd INTERNATIONAL SCIENTIFIC CONFERENCE Palanga, Litvánia : Kaunas University of Technology, (2019) pp. 744-747. , 4 p. 